\title{
Long-distance electron transport by cable bacteria in mangrove sediments
}

\author{
Laurine D. W. Burdorf ${ }^{1, *}$, Silvia Hidalgo-Martinez ${ }^{1}$, Perran L. M. Cook $^{2}$, \\ Filip J. R. Meysman ${ }^{1,3}$ \\ ${ }^{1}$ Department of Ecosystem Studies, The Netherlands Institute of Sea Research (NIOZ), Korringaweg 7, 4401 NT Yerseke, \\ The Netherlands \\ ${ }^{2}$ Water Studies Centre, School of Chemistry, Monash University, Clayton, VIC 3800, Australia \\ ${ }^{3}$ Department of Analytical, Environmental and Geo-Chemistry, Vrije Universiteit Brussel, Pleinlaan 2, 1050 Brussel, Belgium
}

\begin{abstract}
Cable bacteria are long, filamentous sulphur-oxidizing bacteria that induce long-distance electron transport in aquatic sediments. They turn the seafloor into an electro-active environment, characterized by currents and electrical fields, and when present, they exert a strong impact on the geochemical cycling in the seafloor. However, cable bacteria have only recently been discovered, and so their geographical distribution and habitat distribution remain largely unknown. Here we report field evidence that cable bacteria are present and active in mangrove sediments. Combining microsensor profiling and fluorescence in situ hybridization, we recorded high filament densities $\left(77 \mathrm{~m} \mathrm{~cm}^{-2}\right)$ and the signature of electrogenic sulphur oxidation in sediments of grey mangroves near Melbourne, Australia. Our findings suggest that cable bacteria could be a keystone microbial species in the geochemical cycling of mangroves.
\end{abstract}

KEY WORDS: Electrogenic sulphur oxidation • Geomicrobiology - Mangrove sediment biogeochemisty · Long-distance electron transport - Cable bacteria

\section{INTRODUCTION}

Cable bacteria are long, multicellular, filamentous bacteria (Pfeffer et al. 2012) that induce long-distance electron transport in sediments (Nielsen et al. 2010). Individual filaments are vertically oriented in the sedi-

*Corresponding author: laurine.burdorf@nioz.nl

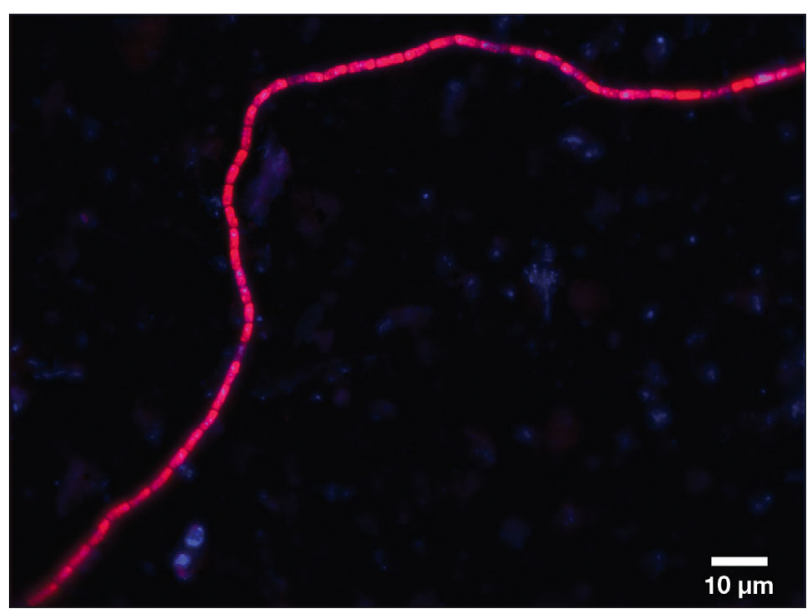

Cable bacterium from mangrove sediments, stained with fluorescent in situ hybridization (probe: DSB706)

Image: Silvia Hidalgo-Martinez

ment, can be several centimetres long, and can incorporate over $10^{4}$ cells. Cable bacteria have a unique metabolism, referred to as electrogenic sulphur oxidation (e-SOx), which generates an electrical current between distant parts of the bacterial filament (Nielsen \& Risgaard-Petersen 2015). Electrons are harvested from sulphide oxidation in deeper layers of the sediment and are subsequently transported upwards along the longitudinal axis of the filaments. Within the top layer of the sediment, these electrons are finally supplied to a terminal electron acceptor, such as oxygen (Nielsen et al. 2010) or nitrate (Marzocchi et al. 2014).

() The authors 2016. Open Access under Creative Commons by Attribution Licence. Use, distribution and reproduction are unrestricted. Authors and original publication must be credited. 
The metabolic activity of cable bacteria has a strong imprint on the geochemistry of marine sediments (Risgaard-Petersen et al. 2012, Rao et al. 2016). Concurrent with the development of a cable bacteria community in the sediment, a suboxic zone develops, i.e. a zone devoid of free sulphide and oxygen (Schauer et al. 2014). Over time, this suboxic zone gradually expands downwards, and recent field observations show that the width of the suboxic zone may eventually exceed $5 \mathrm{~cm}$ (Schauer et al. 2014, Rao et al. 2016). The spatial segregation of redox half-reactions also leads to a specific $\mathrm{pH}$ signature in the pore water of the sediment (Nielsen et al. 2010, Meysman et al. 2015). The oxidation of sulphide at depth leads to proton production, while the reduction of oxygen or nitrate in the top sediment entails proton consumption. This generates a characteristic $\mathrm{pH}$ depth profile, consisting of a narrow $\mathrm{pH}$ maximum in the top layer of the sediment and a broad $\mathrm{pH}$ minimum deeper in the sediment (Nielsen et al. 2010, Meysman et al. 2015). Because of their strong impact on the pore water $\mathrm{pH}$ of the sediment, cable bacteria stimulate the cycling of other elements, such as calcium, iron and manganese (Risgaard-Petersen et al. 2012, Meysman et al. 2015, Rao et al. 2016).

As cable bacteria have only recently been discovered, field observations to date are sparse, meaning that the natural distribution of cable bacteria remains poorly documented. As a result, it remains uncertain how important cable bacteria and e-SOx are for the sulphur cycle of aquatic sediments. So far, high abundances and strong metabolic activity of cable bacteria have been reported from various coastal habitats within the southern North Sea (Malkin et al. 2014, Seitaj et al. 2015) and from a freshwater stream in Denmark (Risgaard-Petersen et al. 2015). However, analysis of 16S rRNA gene archives indicates a much wider geographical distribution and suggests cable bacteria could be present and active in many other marine habitats (Malkin et al. 2014). Of particular interest is the fact that the 16S rRNA archive contains sequences from a tropical mangrove at the Futian National Nature Reserve, China (Liang et al. 2007) which are highly similar to the 16S rRNA sequences of cable bacteria recovered from the southern North Sea (Malkin et al. 2014).

This suggests that cable bacteria could potentially be important in the biogeochemical cycling of mangrove sediments. To verify this hypothesis, we examined the sediments of a temperate mangrove system along the southern coast of Australia in Victoria (Fig. 1). We combined field sampling as well as laboratory sediment incubations to assess the presence and activity of cable bacteria in the mangrove sediments.

\section{MATERIALS AND METHODS}

\author{
Site description
}

Sediments were sampled at 2 sites near the city of Melbourne, Australia (Fig. 1a) in February 2014 (Site 1: Western Port, $38.633^{\circ} \mathrm{S}, 145.183^{\circ} \mathrm{E}$; Site 2: Anderson Inlet, $38.229^{\circ} \mathrm{S}, 145.309^{\circ} \mathrm{E}$ ). Both sites are characterized by a mangrove forest exclusively composed of Avicennia marina subsp. australasica (Duke 1991, Boon et al. 2011; Fig.1b). Small plastic core liners (diameters 7 and $11 \mathrm{~cm}$; length 7 to $15 \mathrm{~cm}$ ) were manually pushed into the sediment to collect sediment cores at low tide. These cores were immediately transferred to a nearby laboratory (Water Studies Centre, Monash University, Melbourne). Sediment from Site 1 was profiled with micro-electrodes within $12 \mathrm{~h}$ of core collection and subsequently sectioned at $0.5 \mathrm{~cm}$ intervals up to $3 \mathrm{~cm}$ depth for fluorescence in situ hybridization (FISH) analysis. Sediment from Site 2 contained an abundance of plant roots and could not be profiled (risk of breaking micro-electrodes was too high). Instead, the sediment was used for a laboratory induction experiment as described below.

\section{Laboratory sediment incubations}

Sediment collected from Site 2 was prepared using the enrichment procedure described by Nielsen et al. (2010) and Malkin et al. (2014). Sediment was first homogenized and sieved to remove fauna $(0.5 \mathrm{~mm}$ mesh size) and subsequently packed into plastic core liners ( $4 \mathrm{~cm}$ inner diameter; 7 to $9 \mathrm{~cm}$ height). Sediment cores were then placed in an aquarium with seawater, which was constantly aerated through air bubbling at $25^{\circ} \mathrm{C}$. After $12 \mathrm{~d}$ of incubation, the cores were profiled with micro-electrodes and sectioned for FISH analysis as described above.

\section{FISH analysis}

At each depth, $0.5 \mathrm{ml}$ of sediment was preserved in $0.5 \mathrm{ml}$ of $96 \%$ ethanol, and stored at $-20^{\circ} \mathrm{C}$. Analysis was done with the probe DSB706 (Manz et al. 1992) as described by Schauer et al. (2014), which targets most Desulfobulbaceae and Thermodesulforhabdus. This probe has previously been shown to successfully hybridize with cable bacteria filaments (Pfeffer et al. 2012, Malkin et al. 2014, Schauer et al. 2014, Seitaj et al. 2015, Vasquez-Cardenas et al. 2015). 


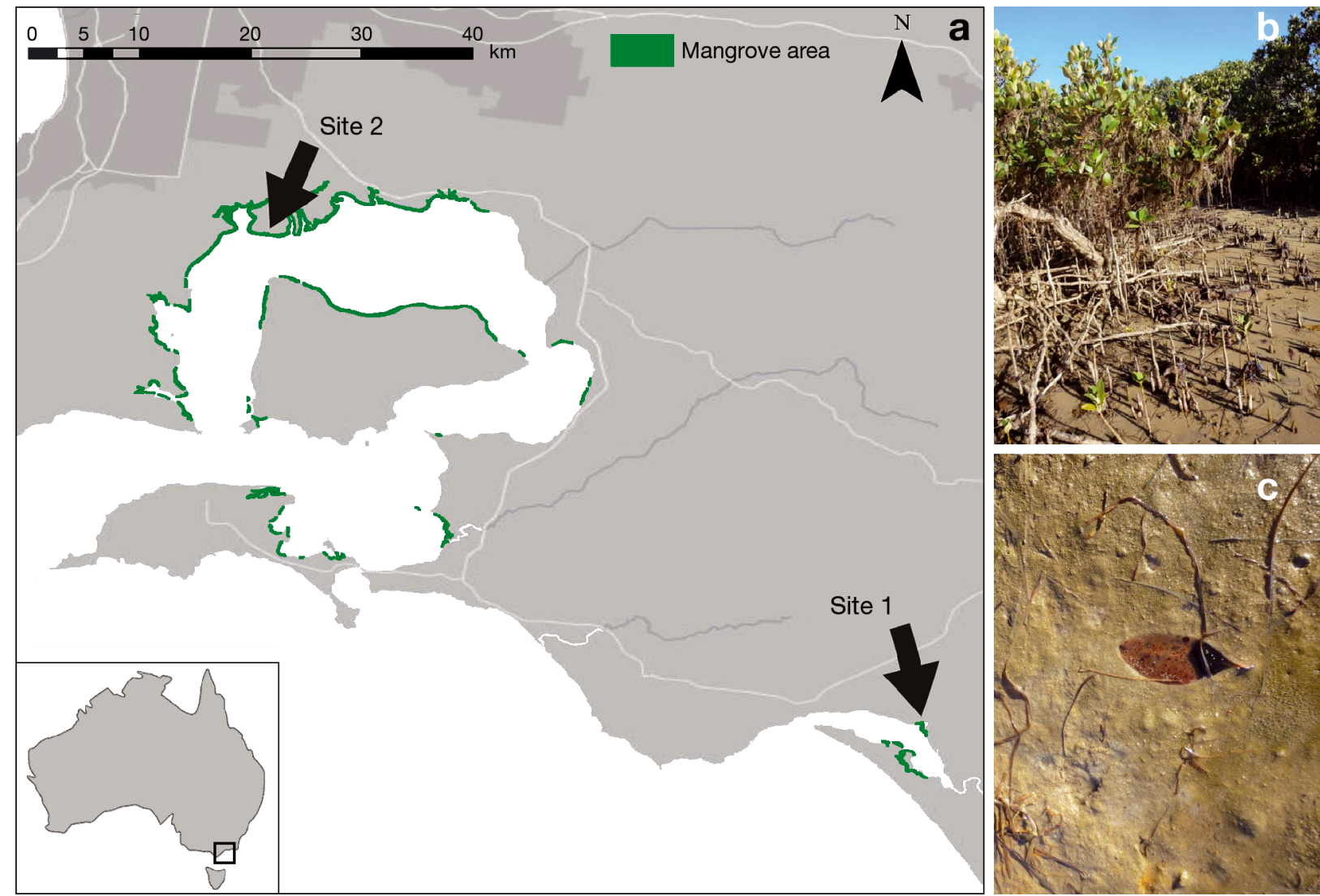

Fig. 1. (a) Two sampling sites used in this study in Victoria, Australia. (b) Both mangrove sites are characterized by a singlespecies mangrove (Avicennia marina subsp. australasica). (c) Close-up of the sediment surface at Site 2

\section{Microsensor profiling}

In each sediment core, 2 sets of pore water depth profiles of $\mathrm{O}_{2}, \mathrm{pH}$ and $\mathrm{H}_{2} \mathrm{~S}$ were recorded using commercial micro-electrodes (tip size $\mathrm{pH}$ : $200 \mu \mathrm{m}_{i} \mathrm{H}_{2} \mathrm{~S}$ : $100 \mu \mathrm{m}_{;} \mathrm{O}_{2}: 50 \mu \mathrm{m}$; Unisense) operated with a motorized micromanipulator (Unisense). Oxygen depth profiles were separately recorded with $100 \mu \mathrm{m}$ resolution, while $\mathrm{pH}$ and $\mathrm{H}_{2} \mathrm{~S}$ were concurrently recorded with $200 \mu \mathrm{m}$ resolution in the oxic zone of the sediment and with an increasing step size in the deeper layers of the sediment. The sensors were calibrated using standard calibration procedures as described by Seitaj et al. (2015).

\section{RESULTS}

\section{Fine-scale pore water measurements}

The intact sediment cores retrieved at Site 1 showed a broad zone of low pH extending between 7 and $20 \mathrm{~mm}$ depth (Fig. 2a). Free sulphide remained undetectable $\left(\left[\mathrm{H}_{2} \mathrm{~S}\right]<1 \mu \mathrm{M}\right)$ over the first $12 \mathrm{~mm}$ within the sediment, after which the concentration increased and stabilized at $\sim 7 \mu \mathrm{M}$. The $\mathrm{pH}$ minimum $\left(\mathrm{pH}_{\min }=6.4-6.5,13.2 \mathrm{~mm}\right.$ deep $)$ was located right at the sulphide appearance depth (SAD, defined as the depth where the concentration of $\mathrm{H}_{2} \mathrm{~S}$ first exceeds $1 \mu \mathrm{M})$. No oxygen measurements were available for the field cores, as the micro-electrode broke during the measurements. Visual inspection of the core, however, showed a narrow, yellow oxidized layer of 1 to $3 \mathrm{~mm}$.

After $12 \mathrm{~d}$ of incubation, the laboratory sediment incubations provided a highly similar set of microsensor depth profiles. The shape of the $\mathrm{H}_{2} \mathrm{~S}$ and $\mathrm{pH}$ depth profiles was similar to those of the field cores, and again the $\mathrm{pH}$ minimum $\left(\mathrm{pH}_{\min }=6.3\right)$ was located near the SAD (8.4-9 $\mathrm{mm})$. The oxygen penetration depth (OPD) was $1.1 \mathrm{~mm}$, thus providing a suboxic zone of 6-8 $\mathrm{mm}$ width (defined as the zone with no measurable free oxygen or free sulphide). The acidification intensity $\Delta \mathrm{pH}$ (defined as the highest $\mathrm{pH}$ in the oxic zone minus $\mathrm{pH}_{\min }$ ) was slightly higher in the lab incubations $(\Delta \mathrm{pH}=2.1)$ than in the field $(\Delta \mathrm{pH}=1.6)$. 

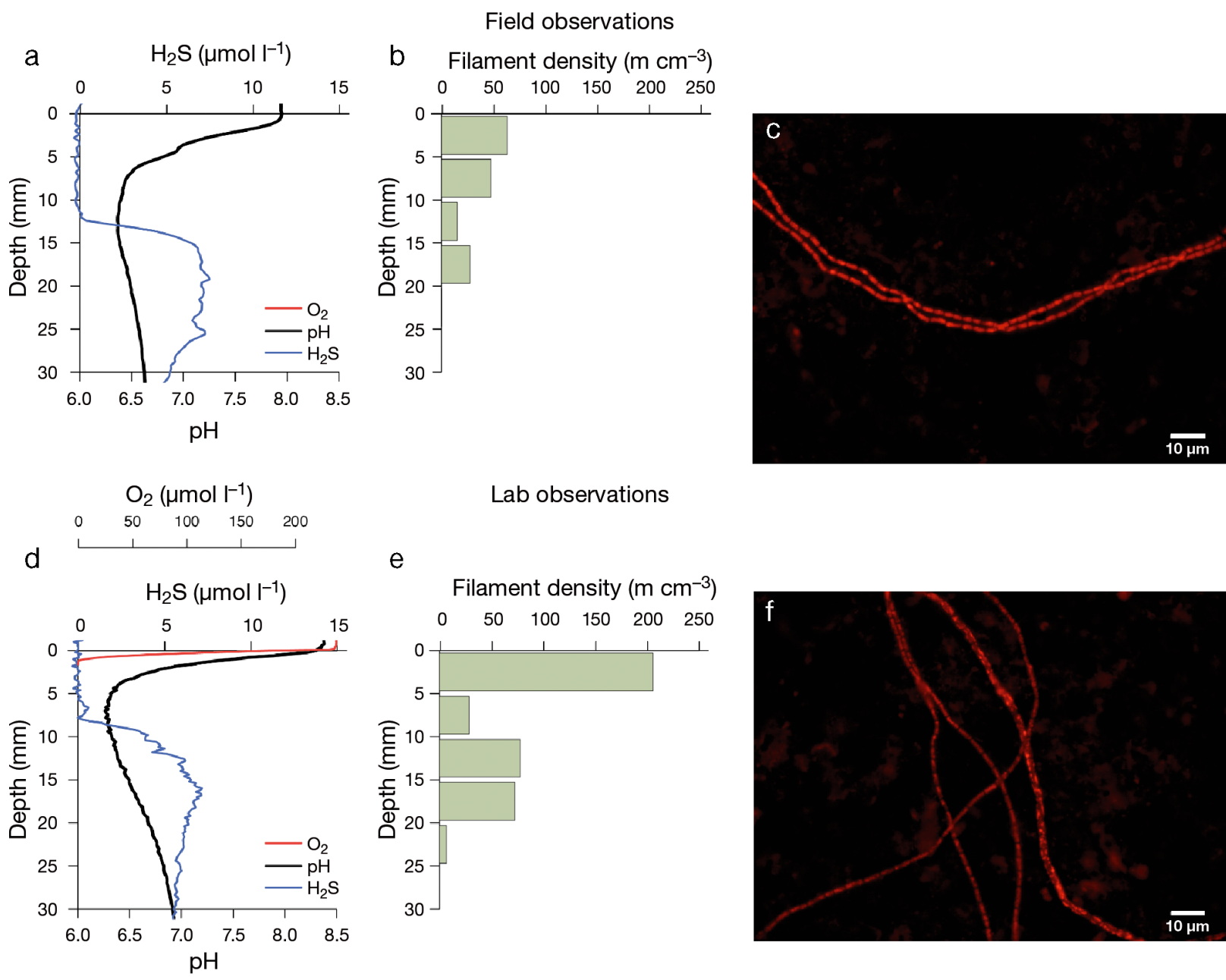

Lab observations

e Filament density $\left(\mathrm{m} \mathrm{cm}^{-3}\right)$
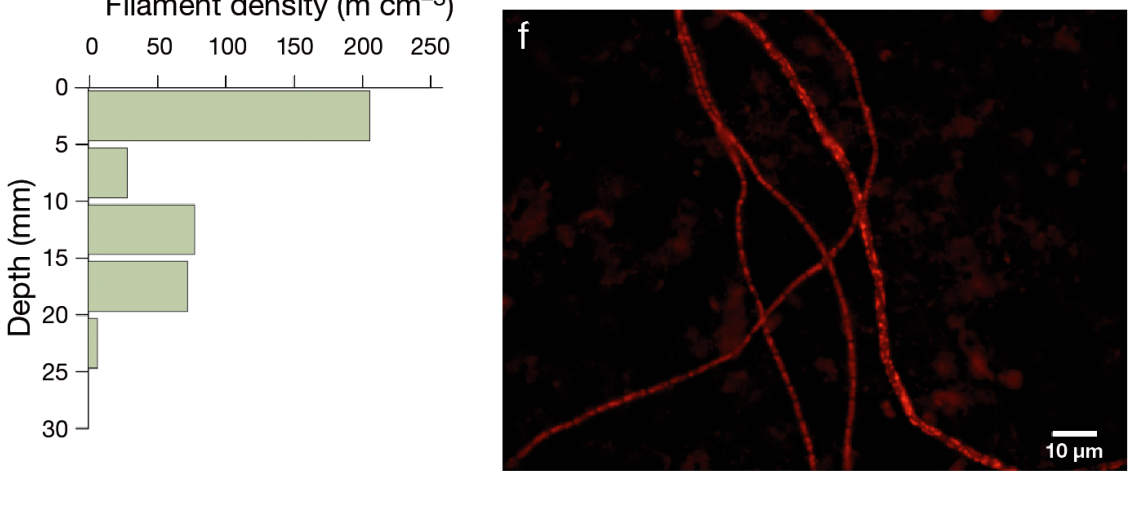

Fig. 2. $(\mathrm{a}, \mathrm{b}, \mathrm{c})$ Results of the field sampling at Site $1 ;(\mathrm{d}, \mathrm{e}, \mathrm{f}$,$) laboratory sediment incubations with sediment collected from Site 2$. $(\mathrm{a}, \mathrm{d})$ Detailed microsensor profiles of $\mathrm{H}_{2} \mathrm{~S}, \mathrm{O}_{2}$ and $\mathrm{pH}$ of the sediment pore water indicate an active cable bacteria population. No $\mathrm{O}_{2}$ data available in (a) due to broken sensor. (b,e) Enumeration of cable bacteria using fluorescence in situ hybridization (FISH) confirms their presence in situ at Site 1 and in a laboratory sediment incubation at Site 2. (c,f) Representative images of cable bacteria from the FISH analysis

\section{FISH analysis}

Cable bacteria filaments were identified by the FISH (DSB706 probe) in both the field cores and laboratory incubations (Fig. 2c,f). The depth distribution of cable bacteria was similar in both field and laboratory: high densities were recorded in the first $2 \mathrm{~cm}$, after which the density became low to undetectable. The density of cable bacteria integrated over the first $2 \mathrm{~cm}$ was higher in the laboratory sample $(196 \mathrm{~m}$ $\left.\mathrm{cm}^{-2}\right)$ compared to the field sample $\left(77 \mathrm{~m} \mathrm{~cm}^{-2}\right)$. The laboratory incubations showed a clear enrichment in the (oxic) surface layer, with a filament density of $206 \mathrm{~m} \mathrm{~cm}^{-3}$, which was more than twice as high as in consecutive layers (max. $79 \mathrm{~m} \mathrm{~cm}^{-3}$ ). In contrast, the field cores showed a more even depth distribution of cable filament densities. The mean diameter of the counted cable bacteria did not differ significantly
(Mann-Whitney $U$-test, $\mathrm{p}>0.05$ ) between the field $(1.3 \pm 0.5 \mu \mathrm{m})$ and laboratory cores $(1.0 \pm 0.4 \mu \mathrm{m})$, suggesting that the same morphotype of cable bacteria developed in the laboratory cores as observed in the field.

\section{DISCUSSION}

\section{Long-distance electron transport in mangrove sediments}

Analysis of $16 \mathrm{~S}$ rRNA gene archives has recently brought up the hypothesis that mangrove sediments could form a suitable environment for cable bacteria (Malkin et al. 2014). Our study confirms the presence of cable bacteria in mangrove sediments and shows that their metabolic activity, i.e. the occurrence of 
e-SOx, substantially impacts the geochemical cycling of surface sediments via the removal of sulphide and a strong acidification of deeper sediment horizons. Fine-scale pore water measurements show the geochemical fingerprint of e-SOx within the Avicennia marina habitat. Cable bacteria display a high affinity for free sulphide, leading to a suboxic zone, devoid of any free oxygen or sulphide in the pore water (Nielsen et al. 2010, Meysman et al. 2015). This sulphide depletion below the oxic zone was observed both in the field cores and our laboratory incubations of the mangrove sediments.

However, there are alternative mechanisms that can create a suboxic zone in marine sediments, most notably the down mixing of iron (hydr)oxides by faunal bioturbation (Canfield 1993) or the depletion of sulphide by nitrate-accumulating Beggiatoaceae (Mußmann et al. 2003). As argued in Seitaj et al. (2015), these 3 mechanisms can be discerned by their effect on the depth profile of the porewater $\mathrm{pH}$. Cable bacteria generate a substantial decrease in $\mathrm{pH}$ within the suboxic zone which is consistent with the production of protons during the anodic oxidation of sulphide $\left(\frac{1}{2} \mathrm{H}_{2} \mathrm{~S}+2 \mathrm{H}_{2} \mathrm{O} \rightarrow \frac{1}{2} \mathrm{SO}_{4}^{2-}+4 \mathrm{e}^{-}+5 \mathrm{H}^{+}\right)$The 2 alternative mechanisms, however, generate an increase in $\mathrm{pH}$ in the suboxic zone. The down mixing of iron (hydr)oxides by bioturbation generally leads to a $\mathrm{pH}$ minimum at the base of the oxic zone due to the oxidation of ferrous iron and iron sulphides, followed by an increase in $\mathrm{pH}$ below the oxic zone due to the reduction of iron (hydr)oxides which produces alkalinity. Alternatively, Beggiatoaceae also increase the $\mathrm{pH}$ in the suboxic zone due to the oxidation of sulphide to elemental sulphur via intracellular $\mathrm{NO}_{3}{ }^{-}$, a reaction that also produces alkalinity (Seitaj et al. 2015).

Microsensor depth profiles obtained in the lab incubation (which purposely excluded bioturbating fauna by sieving) are very similar to the field recordings (Fig. 2). Both measurements show a notable acidification of the pore water within the suboxic zone (acidification intensities $\Delta \mathrm{pH}=1.8-2.1$ ), which is consistent with the excess production of protons during anodic sulphide oxidation by cable bacteria. In contrast, the shallow pH maximum within the oxic zone, which is typically associated with proton consumption during cathodic reduction of oxygen $\left(\mathrm{O}_{2}+4 \mathrm{e}^{-}+4 \mathrm{H}^{+} \rightarrow 2 \mathrm{H}_{2} \mathrm{O}\right)$ was not detected. However, recent observations suggest that this shallow $\mathrm{pH}$ maximum is not as characteristic for e-SOx as originally thought (Seitaj et al. 2015, Sulu-Gambari et al. 2015). Microsensor profiling at field sites where e-SOx is active reveals that the shallow $\mathrm{pH}$ maximum is not always present, in contrast to the pH minimum, which is always there (Seitaj et al. 2015).
The absence of the $\mathrm{pH}$ maximum can be explained by 3 factors: (1) Electrogenic sulphur oxidation does not need to create a subsurface $\mathrm{pH}$ maximum. The cathodic reduction of oxygen consumes protons, and hence generates alkalinity. Theoretically, the production of a solute only requires the concentration depth profile to be upwards concave. This is a weaker constraint than the existence of a subsurface maximum. Therefore, the inflection of the $\mathrm{pH}$ gradient in the oxic zone, as observed in the 2 sediment profiles reported here (Fig. 2), is a sufficient indication of local alkalinity generation. (2) The alkalinity in the overlying water is much lower than in the oxic layer, and so there is an export of alkalinity by diffusion across the sediment water interface. The diffusive export of a solute occurs more efficiently when its production occurs closer to the sediment water interface. Therefore, in highly reactive sediments with narrow oxic zones (here OPD $<1.2 \mathrm{~mm}$ ), the export of alkalinity by diffusion is rapid, and this makes the establishment of a $\mathrm{pH}$ maximum increasingly difficult. (3) Microsensor profiling could underestimate strong $\mathrm{pH}$ gradients due to profile smoothing by the relatively large length of the $\mathrm{pH}$ sensitive glass at the tip of the micro-electrode (250-350 $\mu \mathrm{m})$ compared to the distance of which the $\mathrm{pH}$ gradient changes $(\sim 500 \mu \mathrm{m})$. Overall, we conclude that the observed combination of $\mathrm{H}_{2} \mathrm{~S}, \mathrm{pH}$ and $\mathrm{O}_{2}$ profiles in both laboratory and field cores can be interpreted as a signature of e-SOx, and hence, cable bacteria were metabolically active in the mangrove sediments investigated.

\section{Density and activity of cable bacteria in mangrove sediments}

The acidification intensity and density of cable bacteria as observed in the mangrove sediments were within the range reported for other sites (Table 1). Depth-integrated FISH counts show that $77 \mathrm{~m}$ of cable bacteria filaments $\mathrm{cm}^{-2}$ were present at the mangrove site. Assuming that all cable bacteria are vertically oriented in the sediment and that the filaments span the whole suboxic zone (length = $7 \mathrm{~mm}$ ), the areal density of cable bacteria can be calculated as $1.1 \times 10^{8}$ filaments $\mathrm{m}^{-2}$. Accordingly, the mean horizontal distance between 2 cable bacteria filaments in the sediment would be $\sim 95 \mu \mathrm{m}$, which illustrates the dense character of the filament network.

The recorded filament density of $77 \mathrm{~m} \mathrm{~cm}^{-2}$ is 2-fold higher than field observations from a freshwater 
Table 1. Literature compilation for the reported cable bacteria densities and activity. A distinction is made between field and laboratory measurements. Areal densities of cable bacteria are derived from FISH enumeration (depth integrated). Cable bacteria activity is represented by the acidification intensity $(\Delta \mathrm{pH})$, which expresses the difference between the highest $\mathrm{pH}$ recorded in the oxic zone and the lowest $\mathrm{pH}$ recorded within the suboxic zone. na: not available. (1) Present study, (2) Larsen et al. (2014), (3) Vasquez-Cardenas et al. (2015), (4) Seitaj et al. (2015), (5) Schauer et al. (2014), (6) Nielsen et al. (2010), (7) Risgaard-Petersen et al. (2015)

\begin{tabular}{|llccc|}
\hline \multirow{2}{*}{ Habitat type } & Location & \multicolumn{2}{c|}{ Density $\left(\mathrm{m} \mathrm{cm}^{-2}\right)$} & \multicolumn{2}{c|}{ Intensity $(\Delta \mathrm{pH})$} \\
& & Lab & Field & Lab \\
\hline Mangrove & Victoria (AU) & $196^{(1)}$ & $77^{(1)}$ & $2.1^{(1)}$ \\
Salt marsh & New England (USA) & $150-200^{(2)}$ & na & $1.0^{(2)}$ \\
Seasonal hypoxic lake & Grevelingen (NL) & $1131^{(3)}$ & $259^{(4)}$ & $2.6^{(3)}$ \\
Coastal zone & Aarhus Bay (DK) & $2380^{(5)}$ & na & $1.3^{(4)}$ \\
Freshwater & Giber A (DK) & na & $40^{(7)}$ & na \\
& & & $2.5^{(6)}$ \\
\hline
\end{tabular}

stream in Denmark $\left(40 \mathrm{~m} \mathrm{~cm}^{-2}\right.$; Risgaard-Petersen et al. 2015), but 3-4 times lower than densities reported for sediments in the seasonally hypoxic marine Lake Grevelingen (259 m cm${ }^{-2}$; Seitaj et al. 2015).

Previous studies have shown that acidification of the pore water by cable bacteria directly leads a substantial remobilization of $\mathrm{Fe}^{2+}$ and $\mathrm{Ca}^{2+}$ (RisgaardPetersen et al. 2012, Rao et al. 2016). The acidification intensity $\Delta \mathrm{pH}$ (defined as the maximum $\mathrm{pH}$ in the oxic zone minus the $\mathrm{pH}$ minimum at the sulphide apparition depth) is interpreted here as an indicative measure of the impact of cable bacteria on the geochemical cycling. The magnitude of $\Delta \mathrm{pH}$ is the combined result of the metabolic activity of the cable bacteria (i.e. the proton release by anodic sulphide oxidation) and the buffering capacity of the sediment (i.e. the content of $\mathrm{FeS}$ and $\mathrm{CaCO}_{3}$ minerals, the dissolution of which counteracts a $\mathrm{pH}$ decrease of the pore solution). Accordingly, in sediments with similar buffering capacity, the acidification intensity will scale with the metabolic activity of the cable bacteria. The larger the cable bacteria activity, the stronger the local alkalinity consumption, and hence the lower the $\mathrm{pH}$ minimum. Yet, when comparing sediments with different buffer capacities, $\Delta \mathrm{pH}$ is no longer a strict measure of cable bacteria activity, but it still remains a first-order indicator of how cable bacteria affect the sediment geochemistry.

The acidification intensity recorded at the mangrove field site $(\Delta \mathrm{pH}=1.6)$ is higher than in the marine sediments previously investigated $(\Delta \mathrm{pH}=$ 1.3-1.4; Table 1), suggesting that e-SOx was a dominant component in the proton cycling of the pore water. Only a freshwater cable bacteria site, of which the pore water presumably had a much lower buffering capacity against $\mathrm{pH}$ perturbations, has revealed a higher acidification intensity $(\Delta \mathrm{pH}=2.3$; RisgaardPetersen et al. 2015).
In line with previous investigations, the in situ density of cable bacteria $\left(77 \mathrm{~m} \mathrm{~cm}^{-2}\right)$ was lower compared to the density obtained in defaunated, homogenized sediments that were incubated under laboratory conditions $\left(196 \mathrm{~m} \mathrm{~cm}^{-2}\right)$. This latter density is similar to the previously reported value obtained during enrichment of temperate salt marsh sediment (150-200 $\mathrm{m} \mathrm{cm}^{-2}$; Larsen et al. 2015) but lower than laboratory incubations with sediment from Marine Lake Grevelingen (>1000 $\mathrm{m} \mathrm{cm}^{-2}$; Vasquez-Cardenas et al. 2015) and Aarhus Bay (>2000 m cm${ }^{-2}$; Schauer et al. 2014).

In laboratory sediment incubations, cable bacteria have shown a characteristic development process, consisting of a lag period of 5-10 d, after which the population grows exponentially over a period of 2 to 4 wk (Schauer et al. 2014, Rao et al. 2016). The incubation of our mangrove sediment was rather short (12 d), which could explain the lower densities obtained compared to higher numbers reported before. The higher cable filament density observed in our laboratory enrichments clearly increases the acidification intensity compared to the field $(\Delta \mathrm{pH}=2.1$ vs. $\Delta \mathrm{pH}=1.6$ in the field). Assuming that sediment homogenization does not affect the sedimentary buffering capacity, this implies cable bacteria activity is higher under laboratory conditions. A similar stimulation of e-SOx under laboratory conditions has been observed in previous studies (see references given in Table 1) and has been attributed to the increased availability of iron sulphides in the top layer of homogenized sediments.

\section{Geographical distribution and habitat diversity of cable bacteria}

Cable bacteria, which perform e-SOx through long-distance electron transport, have to date mostly 
been found in fine-grained muddy sediments characterized by high organic carbon content and a high supply of sulphide through sulphate reduction (Malkin et al. 2014). Therefore, it is not unsurprising that mangrove sediments also sustain cable bacteria activity: mangrove sediments have a high organic carbon content due to litterfall (Aller et al. 2004, Bouillon et al. 2008, Deborde et al. 2015), and in most cases sulphate reduction is the most important pathway of organic matter mineralization (Kristensen et al. 2008). However, unlike previously sampled sites, mangroves are subject to a bioturbation regime imposed by macrofauna such as fiddler crabs and ghost shrimps (Kristensen \& Alongi 2006). Even though fiddler crabs do not occur at the mangrove sites investigated here, ocypodid crabs and ghost shrimps are known to rework the sediment (Katrak \& Bird 2003). Bioturbation has been put forward as a major constraint on the distribution of cable bacteria: macro-benthos is able to mechanically cut the bacterial 'power cords' while reworking the sediment (Malkin et al. 2014). Two arguments support this hypothesis: (1) pulling a wire through the sediment leads to an immediate collapse of the geochemical signature of e-SOx (Pfeffer et al. 2012, Vasquez-Cardenas et al. 2015), and (2) the addition of bioturbating fauna to sediment cores inhibits the growth of a cable bacteria community (Malkin et al. 2014, Rao et al. 2014). Here, however, our field data show the presence and activity of cable bacteria in bioturbated sediments. Potentially, the frequency with which sediment patches are reworked by fauna could provide an explanation. Given the observed fast growth of cable bacteria populations (Schauer et al. 2014, Rao et al. 2016) and the heterogeneity of the effect of bioturbators on marine sediments (Michaud et al. 2006, Braeckman et al. 2010), it is not unlikely that cable bacteria can develop if a certain patch of sediment is left untouched by bioturbating fauna for a sufficiently long period of time (12 d or less, as in our laboratory incubations). This observation that cable bacteria are also active in bioturbated sediments could widely extend the potential geographical distribution of cable bacteria.

\section{Impact of cable bacteria on geochemical cycling in mangrove sediments}

Based on the results obtained here, the reported 16S rRNA cable bacteria sequences in a Chinese mangrove (Liang et al. 2007) and earlier reported $\mathrm{pH}$ minima in the sediment top layer of a mangrove sediment from New Caledonia (Molnar et al. 2014), we expect that cable bacteria activity could be widespread in mangrove sediments. Given the strong impact that cable bacteria have on the iron, sulphur and carbon cycling in other coastal sediments (Risgaard-Petersen et al. 2012, Seitaj et al. 2015, Rao et al. 2016), e-SOx may strongly influence geochemical cycling in mangrove sediments. To verify this hypothesis, future studies are needed which focus on a more detailed description of the pore water and solid phase geochemistry of mangrove sediments that are electro-active.

Acknowledgements. We thank Elizabeth Robertson for providing the mangrove images and Fiona Warry and Victor Evrard for their help and advice during the sampling campaigns. This research was financially supported by the European Research Council under the European Union's Seventh Framework Programme (FP/2007-2013) through ERC Grant 306933 to F.J.R.M.

\section{LITERATURE CITED}

Aller RC, Heilbrun C, Panzeca C, Zhu Z, Baltzer F (2004) Coupling between sedimentary dynamics, early diagenetic processes, and biogeochemical cycling in the Amazon-Guianas mobile mud belt: coastal French Guiana. Mar Geol 208:331-360

Boon PL, Allen T, Brook J, Carr G and others (2011) Mangroves and coastal saltmarsh of Victoria: distribution, condition, threats and management. Victoria University, Melbourne

> Bouillon S, Borges AV, Castañeda-Moya E, Diele K and others (2008) Mangrove production and carbon sinks: a revision of global budget estimates. Glob Biogeochem Cycles 22:GB2013, doi:10.1029/2007GB003052

Braeckman U, Provoost P, Gribsholt B, Van Gansbeke D and others (2010) Role of macrofauna functional traits and density in biogeochemical fluxes and bioturbation. Mar Ecol Prog Ser 399:173-186

Canfield DE (1993) Organic matter oxidation in marine sediments. In: Wollast R, Mackenzie FT, Chou L (eds) Interactions of $\mathrm{C}, \mathrm{N}, \mathrm{P}$ and $\mathrm{S}$ biogeochemical cycles and global change. Springer-Verlag, Berlin, p 333-363

Deborde J, Marchand C, Molnar N, Patrona L, Meziane T (2015) Concentrations and fractionation of carbon, iron, sulfur, nitrogen and phosphorus in mangrove sediments along an intertidal gradient (semi-arid climate, New Caledonia). J Mar Sci Eng 3:52-72

> Duke NC (1991) A systematic revision of the mangrove genus Avicennia (Avicenniaceae) in Australasia. Aust Syst Bot 4:299-324

Katrak G, Bird FL (2003) Comparative effects of the large bioturbators, Trypaea australiensis and Heloecius cordiformis, on intertidal sediments of Western Port, Victoria, Australia. Mar Freshw Res 54:701-708

Kristensen E, Alongi DM (2006) Control by fiddler crabs (Uca vocans) and plant roots (Avicennia marina) on carbon, iron, and sulfur biogeochemistry in mangrove sediment. Limnol Oceanogr 51:1557-1571 
Kristensen E, Bouillon S, Dittmar T, Marchand C (2008) Organic carbon dynamics in mangrove ecosystems: a review. Aquat Bot 89:201-219

Larsen S, Nielsen LP, Schramm A (2015) Cable bacteria associated with long-distance electron transport in New England salt marsh sediment. Environ Microbiol Rep 7: 175-179

Liang JB, Chen YQ, Lan CY, Tam NFY, Zan QJ, Huang LN (2007) Recovery of novel bacterial diversity from mangrove sediment. Mar Biol 150:739-747

Malkin SY, Rao AMF, Seitaj D, Vasquez-Cardenas D and others (2014) Natural occurrence of microbial sulphur oxidation by long-range electron transport in the seafloor. ISME J 8:1843-1854

- Manz W, Amann R, Ludwig W, Wagner M, Schleifer KH (1992) Phylogenetic oligodeoxynucleotide probes for the major subclasses of Proteobacteria: problems and solutions. Syst Appl Microbiol 15:593-600

Marzocchi U, Trojan D, Larsen S, Meyer RL and others (2014) Electric coupling between distant nitrate reduction and sulfide oxidation in marine sediment. ISME J 8: 1682-1690

Meysman FJR, Risgaard-Petersen N, Malkin SY, Nielsen LP (2015) The geochemical fingerprint of microbial longdistance electron transport in the seafloor. Geochim Cosmochim Acta 152:122-142

Michaud E, Desrosiers G, Mermillod-Blondin F, Sundby B, Stora G (2006) The functional group approach to bioturbation: II. The effects of the Macoma balthica community on fluxes of nutrients and dissolved organic carbon across the sediment-water interface. J Exp Mar Biol Ecol 337:178-189

Molnar N, Marchand C, Deborde J, Patrona LD, Meziane T (2014) Seasonal pattern of the biogeochemical properties of mangrove sediments receiving shrimp farm effluents (New Caledonia). J Aquac Res Dev 5:1-13

Mußmann M, Schulz HN, Strotmann B, Kjær T and others (2003) Phylogeny and distribution of nitrate-storing Beggiatoa spp. in coastal marine sediments. Environ Microbiol 5:523-533

Editorial responsibility: Erik Kristensen, Odense, Denmark
Nielsen LP, Risgaard-Petersen N (2015) Rethinking sediment biogeochemistry after the discovery of electric currents. Annu Rev Mar Sci 7:425-442

Nielsen LP, Risgaard-Petersen N, Fossing H, Christensen PB, Sayama M (2010) Electric currents couple spatially separated biogeochemical processes in marine sediment. Nature 463:1071-1074

Pfeffer C, Larsen S, Song J, Dong M and others (2012) Filamentous bacteria transport electrons over centimetre distances. Nature 491:218-221

Rao AMF, Malkin SY, Montserrat F, Meysman FJR (2014) Alkalinity production in intertidal sands intensified by lugworm bioirrigation. Estuar Coast Shelf Sci 148:36-47

> Rao AMF, Malkin SY, Hidalgo-Martinez S, Meysman FJR (2016) The impact of electrogenic sulfide oxidation on elemental cycling and solute fluxes in coastal sediment. Geochim Cosmochim Acta 172:265-286

> Risgaard-Petersen N, Revil A, Meister P, Nielsen LP (2012) Sulfur, iron-, and calcium cycling associated with natural electric currents running through marine sediment. Geochim Cosmochim Acta 92:1-13

> Risgaard-Petersen N, Kristiansen M, Frederiksen RB, Dittmer AL and others (2015) Cable bacteria in freshwater sediments. Appl Environ Microbiol 81:6003-6011

Schauer R, Risgaard-Petersen N, Kjeldsen KU, Tataru Bjerg JJ, Jørgensen BB, Schramm A, Nielsen LP (2014) Succession of cable bacteria and electric currents in marine sediment. ISME J 8:1314-1322

Seitaj D, Schauer R, Sulu-Gambari F, Hidalgo-Martinez S and others (2015) Cable bacteria generate a firewall against euxinia in seasonally hypoxic basins. Proc Natl Acad Sci USA 112:13278-13283

Sulu-Gambari F, Seitaj D, Meysman FJR, Schauer R, Polerecky L, Slomp CP (2015) Cable bacteria control ironphosphorus dynamics in sediments of a coastal hypoxic basin. Environ Sci Technol 50:1227-1233

Vasquez-Cardenas D, van de Vossenberg J, Polerecky L, Malkin SY and others (2015) Microbial carbon metabolism associated with electrogenic sulphur oxidation in coastal sediments. ISME J 9:1966-1978

Submitted: November 26, 2015; Accepted: January 25, 2016 Proofs received from author(s): March 1, 2016 